\title{
Conative Meanings of Covid-19 Hate Speech on Social Media in the Perspective of Substantive Arguments

\author{
Yuliana Setyaningsih
}

\begin{abstract}
This study aims to describe the results of the analysis of the conative meanings of Covid-19 hate speech on social media. The data of this study were excerpts from Covid-19 hate speech text on social media in March-May 2020. The data were collected by referring to the note taking technique as the basic technique. Data analysis were performed using the content analysis method. The design analysis method used was the estimated content analysis design. This design utilized all the knowledge researchers have in analyzing data about the conative meaning of Covid-19 hate speech. The results showed that Covid-19's hate speech had the following conative meanings: (1) insulting, (2) criticizing, (3) railing, (4) provoking, (5) harrasing, (6) blasheming, (7) insinuating, and (8) defaming. The results of this study are useful for building critical awareness of the community in the face of hate speech that is constantly present through social media in the community.
\end{abstract}

Keywords: conative meanings, hate speech, Covid-19, argument

\section{INTRODUCTION}

Hate speech related to the Covid-19 pandemic has become increasingly severe. Hate speech can be interpreted as an action taken by an individual or a group of individuals in the form of provocation, incitement or insult to another individual or group (https://www.hukumonline.com/berita/baca/lt5cf0a71edb75 c/meluruskan-istilah-kritik--fitnah-dan-ujaran-kebencian-ole h--reda-manthovani/). There are various manifestations of hate speech. Hate speech can be related to race, skin color, ethnicity, gender, physical condition, sexual orientation, religion and others. The Covid-19 pandemic which demands great responsibility from the society, especially from President Jokowi's government which is currently in power, did not escape the targets of the hate speech perpetrators and spreaders. In a legal context, hate speech can refer to words, writings or performance that are prohibited because they can trigger acts of violence and prejudice, either from the perpetrators of the hate speech or the victims of the act. Hate speech can manifest in the following forms: (1) insulting verbally, (2) insulting through letters/written form, (3) slandering, (4) light insults, (5) tattling by slandering, (6) accusations by slandering.

(https://nasional.kompas.com/read/2019/01/31/

17473801/memahami-pasal-ujaran-kebencian-uu-ite-dalamperspektif-kuhp). Those acts can be subject to legal sanctions

Revised Manuscript Received on 05 November, 2020. * Correspondence Author

Yuliana Setyaningsih*, Master Program of Indonesian Language Education, Sanata Dharma University, Yogyakarta, Indonesia. Email: yuliapbsi@gmail.com

(C) The Authors. Published by Blue Eyes Intelligence Engineering and Sciences Publication (BEIESP). This is an open access article under the CC BY-NC-ND license (http://creativecommons.org/licenses/by-nc-nd/4.0/) and prosecuted before the law after a complaint is filed from a certain party. Even though the settlement of hate speech already has a clear legal framework, certain people still commit such dishonorable acts.

Furthermore, in relation to the types of hate speech above, it should be stated that the meaning of the word 'insult' has two meanings, the first meaning is to degrade; to despise (despicable, insignificant); the second meaning is to tarnish, to defame people's reputation, to make dirty; to offend people (such as swearing, insulting) (https://kbbi. kemdikbud.go.id/entri/menghina). From this understanding, the characteristics of hate speech that fall into the category of "insulting" in the context of this study are the written speech that humiliates and offends other people's feelings violently. In line with the meaning of 'insulting', the meaning of 'defaming' is related to tarnishing one's good reputation, degrading or destroying one's good name.

Likewise, the meaning of "rail" is not much different from the word "insult", which means to express that there is a reproach to attack, to condemn and to criticize. In this case, the word 'rail' contains a subjective aspect. That is, the subjective judgment of someone who conveyed the blasphemous act. Since blasphemy has a subjective dimension, the truth of the action is questionable. The word 'provoke' in KBBI is defined as an action that can arouse anger, provoke anger, incite others to do something. (https://kbbi.kemdikbud.go.id/). In connection with the Covid-19 hate speech, the most prominent provocative action is to incite others to do something according to the will of the writer of the hate speech. The main objective of this provocative act with hate speech is to lead public perceptions to destroy the image of other parties. Therefore, the classification used in this study to describe the conative meaning of hate speech arguments are (1) insulting, (2) defaming, (3) railing, (4) provoking and (5) spreading hoax. A study on hate speech has been conducted by Ningrum et al. (2018). In the study, they found that hate speech on the Facebook social media in the form of religious blasphemy was ranked first. The next is hate speech about the spread of hoax, defamation, provocation and incitement. In other studies, for example in the study by Siswanto \& Ermanto (2019), it is revealed that violations of language politeness in the last decade have become a serious phenomenon. The two studies above have a different focus from the study conducted by the researcher because they do not touch the conative meanings of hate speech. In addition, they do not place substantive arguments as a perspective in those studies. Furthermore, it is necessary to convey that the spread of the Covid-19 virus in Indonesia began to develop in early March 2020 should be addressed wisely by every element of the nation without exception.

Published By:

Blue Eyes Intelligence Engineering

\& Sciences Publication

DOI:10.35940/ijmh.D1184.125420

Journal Website: www.ijmh.org

(C) Copyright: All rights reserved.

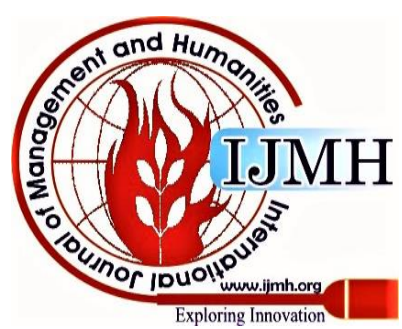


However, there are still a number of people who actually take advantage of this situation to create social discomfort by spreading hate speech on the social media. Social media is online media that is intended to support social communication and interaction. Through social media, everyone can create, edit, publish news, promotions, articles, flexible and broad in scope, social media is also faster and more effective, efficient, interactive and varied. Social media in this cyber era can include a variety of platforms, such as Instagram, Facebook, WhatsApp, Blogs, Websites and so on. Hate speech related to Covid-19 are also scattered on the social media mentioned earlier. Therefore, the critical awareness of the society needs to be built and increased so that they can act appropriately towards the increasing symptoms of the corona virus novel.

In addition to understanding the basic things above, it is also necessary to convey that this study bases the understanding of the meaning of hate speech on the theory of meaning, especially the conative meaning. Conative meaning is defined as a mental process to want, will, intend or try to do something (Ephratt, 2008), (Ameka, 1992). In relation to the meaning of hate speech, what is meant by the conative meaning is interrelated with the desire of the hate speech perpretator to take actions that tend to be negative by fighting

The negative action is carried out by using language, and such language usage can be considered as a manifestation of language preservation. That is, language does not function as it should, but it is being used incorrectly for bad purposes instead (Rahardi, 2018). In accordance with its essence, language should be used to develop reason and strengthen cooperation between one another so that a communio that truly brings one another to life is built. speech. The perspective used in this study is the perspective of Stephen Toulmin's argument (Setyaningsih and Rahardi, 2019). All data in the form of hate speech were analyzed for the quality of the argument, whether the arguments were based on data, or was there no data basis at all (van Eemeren et al., 2013). The results of the hate speech classification are then used to find the meanings of the hate speech arguments. The results of this analysis are expected to be able to educate people who struggle and grapple with hate speech that are present on smartphones in their hands every day.

\section{REVIEW OF THE RELATED LITERATURE}

Hate speech conveyed on social media contains arguments. Those arguments can be divided into two, namely substantive arguments and technical arguments. Substantive arguments refer to arguments whose structure is in accordance with the correct argumentation rules. On the other hand, technical arguments are not based on the principles of those arguments. Furthermore, it is necessary to convey that the theory of substantive argument that underlies this study is the Stephen Toulmin's argument theory.

In line with Toulmin's perspective (1979), a good and complete argument has six components. The six components of the argument are (a) claim, (b) data, (c) warrant, (d) backing, (e) rebuttal and (f) modal qualifier. (Kneuper, 1978), (Setyaningsih and Rahardi, 2019). The first three components are the main components, while the next three components are complementary or additional components. photos and videos by themselves. Apart from being more and tarnishing the image of the other party.

This study focuses on analyzing the meanings of hate

Furthermore, an argument must contain at least three main components, namely components of claim, data,and warrant.

The claim component must be present in an argument. Without a claim, an article cannot be called an argument. The presence of a claim component in the argument must be supported by components of data or fact. An argument will become more qualified if the claim and data are followed by a warrant (Setyaningsih and Rahardi, 2018), (van Eemeren et al., 2013). Additional components such as backing, rebuttal and modal qualifier will make the arguments more complete and robust. However, it is rare that the six components of the argument are present together in an argument construction.

An important component that needs to be understood is the nature of arguments and argumentation (Education, 2019), (van Eemeren et al., 2013). Toulmin et al. (1979) define argumentation as "The term argumentation will be used to refer to the whole activity of making claims, challenging them, backing them up by producing reasons, criticizing those reasons, rebutting those criticisms, and so on." Based on the limitation proposed by Toulmin, argumentation can be interpreted as the whole activity in formulating a position statement (claims), contradicting it, supporting it by producing reasons, criticizing those reasons and fending off those criticisms (Yuliana Setyaningsih, 2013).

As discussed earlier, technical arguments are arguments that do not have a good structure and foundation to be called an argument. Technical arguments in this study are described as arguments that only consist of claim elements and are not supported by other argumentation elements. Such arguments are groundless and are often used for bad purposes. In this Covid-19 pandemic situation, the society must be critical towards technical arguments, especially those related to hate speech on social media. From the researcher's observations in the context of studying hate speech related to the Covid-19 pandemic, utterances on social media that can be categorized as hate speech are the following actions: (1) insulting verbally, (2) insulting through letter / written form, (3) slandering, (4) light insults, (5) tattling by slandering and (6) accusations by slandering. These acts are subject to legal sanctions and can be prosecuted before law after a certain party has filed a complaint. Finally, based on the background, problem identification as well as the theoretical studies presented above, the problem of this study is formulated as follows: What are the conative meanings contained in the Covid-19 hate speech argument on social media? In line with the formulation of the problem, this study aims to describe the conative meaning of Covid-19 hate speech on social media. The results of this study are very useful to build the critical awareness of the society in dealing with hate speech that is constantly present through social media in the society.

\section{METHODOLOGY}

This study was a qualitative descriptive study, which aimed to describe the conative meaning of the Covid-19 hate speech argument on social media. The data sources of this study were news and texts on social media that contained Covid-19 hate speech. The object of this study was the conative meaning of Covid-19 hate speech on social media.

Published By:

Blue Eyes Intelligence Engineering

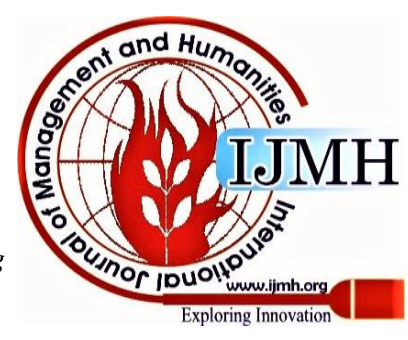


The data of this study were excerpts of texts that contained the conative meaning of Covid-19 hate speech from social media that appeared in March-April 2019.The data were collected by applying the listening method with note-taking techniques (Sudaryanto, 2016), (Mahsun, 2005). Data analysis was carried out using the content analysis method on the substance of the argument in the Covid-19 hate speech (Krippendorff, 2010; 1993; Schilling, 2006). The design of the analysis method used in this study was content analysis design for estimation (Schilling, 2006b). The content analysis design for estimation was chosen because the researcher wanted to examine the conative meaning of Covid-19 hate speech. This design utilizes all the knowledge that the researcher has in analyzing the data based on the type and conative meaning of the Covid-19 hate speech argument which is then interpreted.

The steps of the analysis process were carried out in the following order (1) data formation, (2) data reduction, (3) drawing inference, (4) analysis, and (5) direct validation. The data formation steps included uniting, sampling and recording. Uniting is the activity of cutting or identifying hate speech into units of analysis, which in this case is the argument.

Sampling is an activity of taking samples from a number of analysis units. Recording is an activity to provide coding and descriptions in a form that can be analyzed. The second step was data reduction. In this study, irrelevant data would be deleted. The third step was drawing inference, which was carried out on the types of arguments and their meanings in the hate speech. The analysis step was an activity of describing the type and conative meaning based on pre-determined parameters. The final step was direct validation which would be carried out by experts who master the argument from Stephen Toulmin's perspective.

\section{RESULT AND DISCUSSION}

In line with the formulation of the problem in this study, this section presents the results of the study on the conative meaning of Covid-19 hate speech on social media. The conative meaning of the Covid-19 hate speech argument is identified based on the overall meaning of the argument, which is referred to as the basic meaning and subordinate meaning of parts of the argument in each topic or issue.

The results of data analysis on the conative meaning of hate speech found that there were five categories of basic conative meanings related to Covid-19. The findings of the basic conative meaning are described as follow.

Table 1. Basic Conative Meaning of the Covid-19 Hate Speech Argument

\begin{tabular}{|c|l|c|}
\hline No. & Basic Conative Meaning & $\mathbf{\%}$ \\
\hline 1. & Criticizing & 25 \\
\hline 2. & Railing & 25 \\
\hline 3. & Insinuating & 8 \\
\hline 4. & Insult & 17 \\
\hline 5. & Harass & 25 \\
\hline \multicolumn{2}{|c|}{ Total Amount } & $\mathbf{1 0 0}$ \\
\hline
\end{tabular}

In addition to the basic conative meanings of Covid-19 hate speech, there are also subordinate conative meanings of hate speech. There are eight subordinate conative meanings found in Covid-19 hate speech as can be seen in the following table.
Table 2. Subordinate Conative Meaning of the Covid-19 Hate Speech Argument

\begin{tabular}{|c|l|c|c|}
\hline No. & \multicolumn{1}{|c|}{ Subordinate Conative Meaning } & f & $\mathbf{\%}$ \\
\hline 1. & Condemning someone for wrong action & 12 & 26 \\
\hline 2. & Railing with harsh words & 5 & 10 \\
\hline 3. & $\begin{array}{l}\text { Insinuating to create a chaos with religious } \\
\text { nuance }\end{array}$ & 9 & 19 \\
\hline 4. & Insulting with harsh words & 8 & 17 \\
\hline 5. & Harassing & 5 & 10 \\
\hline 6. & Blaspheming & 3 & 6 \\
\hline 7 & Provoking & 5 & 10 \\
\hline 8 & Defaming & 1 & 2 \\
\hline \multicolumn{2}{|c|}{ Total Amount } & $\mathbf{4 8}$ & $\mathbf{1 0 0}$ \\
\hline
\end{tabular}

The discussion of the conative meaning of hate speech on social media in this study is based on five categories of basic conative meanings, namely (1) insulting, (2) defaming, (3) railing, (4) provoking and (5) spreading hoax. Furthermore, the analysis of the conative meaning is seen from the substance of the argument to find out the types of Covid-19 hate speech, not seen from the context-bound pragmatics aspect. In addition, the aspects of subordinate conative meaning obtained from this study can be conveyed and explained as follow.

\section{A. Conative Meaning of Condemning Someone for Wrong Action}

The argument in the entire hate speech of data 1 is intended to convey criticism on someone's wrong actions. In this context, the claims of speaker A for hate speech contain a conative meaning to condemn the actions of a citizen with an OTG status who is considered wrong because he ran away when isolated.

The conative meaning of condemning wrong actions is the basic meaning, namely the conative meaning that underlies all arguments in the data 1 of the Covid-19 hate speech. In addition to the basic meaning, there is the subordinate meaning in the data 1 argument. The first subordinate meaning is to incite another party to take action against someone.

This can be seen in the hate speech sub-argument which is delivered by speaker D: "Tembak ditempat ajasih org2 yg gk tau diri ini nyusahin pemerintah sama meresahkan masyarakat" (Just shoot those shameless people at sight, always a bothersome to the government and unsettling the society). The second subordinate meaning is to criticize with harsh words, which can be found in speaker F's argument of hate speech, which reads "Itu orng goblok nya luar biasa" (What a big idiot). The word 'goblok' (idiot) falls into the harsh word category.

Thus, the hate speech sub-argument is categorized in the conative meaning of criticizing someone with harsh words. Using language to criticize by using such hate speech is in no way supports the dignity of the Indonesian language (Rahardi, 2009).

Indonesian language can be used widely, even by the international community, not because this language is used to make criticisms, but because it is used by the Indonesian people functionally to optimize the dignity of the language. (Suwardjono, 2008). In this regard, the use of Indonesian language for the preparation and delivery of hate speech should be stopped immediately.

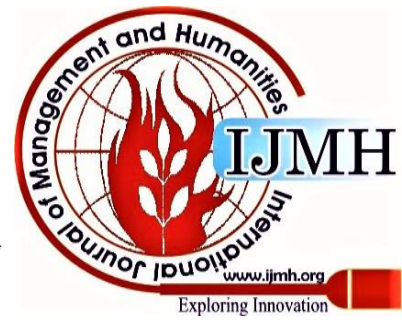




\section{Data 1 Covid-19 Hate Speech}

Positive COVID-19 Patients in Lampung Run Away When Isolated

A : Musnahkan aja orang kek gini. Ga ada otak. Susah payah mau di selamatin dari corona, untuk ngelindungin keluarganya juga, malah kabur.

(Just destroy people like this. They have no brain. People try hard to save him from corona, to protect his family too, but he runs away instead.)

B-A: terlalu kejam bila di musnahkan anda (destroying them is too cruel)

A-B: jgn saya dong om yg musnahin. Minta kim jong un aja. (don't ask me to destroy them. Just ask kim jong un.) gimana klo seandainya itu bagian keluarga anda.

(your life is too savage, sis .. even more than animals .. what if it was a part of your family.)

D: Tembak ditempat ajasih org2 yg gk tau diri ini nyusahin pemerintah sama meresahkan masyarakat

(Just shoot those shameless people at sight, always a bothersome to the government and unsettling the society).

E-D: tembak kan Jan Sampek nggak

(just shoot him, don't let him get away)

D-E: ahahaha untung bkn di kobum dia (ahahaha he's lucky he's not in North Korea)

C-D: serem bos maen tembak aja.. klo keluarga anda yg begitu rela ga bos nembak nya

(you're so scary telling people to just shoot him. If it was your family do you have the heart to shoot)

D-C: maka dari itu tau diri bos kalau penyakit itu cmn matiin diri sendiri oke aja inikan bawa2 org laen

(that's why you need to know your place, it's fine if the disease only kills himself alone, but now he poses danger to others)

F: Itu orng goblok nya luar biasa

(What a big idiot)

https://www.instagram.com/p/B bsvp-giNK/

Context:

A resident of Rawa Laut sub-district in Bandar Lampung with the Person without Symptoms (OTG) status escaped while being isolated in the hospital. Head of the Lampung Provincial Health Office, Reihana, confirmed that the OTG had fled while being isolated at Lampung Provincial Hospital. This news had raised concerns in the society, in which this OTG did not have any symptoms, but was confirmed positive for COVID-19. People with OTG status should be isolated, because even though they appear physically healthy, they have the COVID-19 virus in their bodies which can be transmitted to anyone at any time. Thus, the solution is isolation to prevent the spread of the virus. "Alhamdulillah pasien tersebut, setelah diedukasi oleh petugas surveilans, dia bersedia kembali ke tempat isolasi di rumah sakit Provinsi Lampung," (Thank God, the patient, after being educated by the surveillance officer, was willing to return to the isolation area in Lampung Province hospital), said Reihana.

\section{B. Conative Meaning of Railing with Harsh Words}

Railing is the act of condemning or criticizing harshly. The conative meaning of the overall hate speech arguments in data 2 below is included in the category of railing with harsh words. This can be shown through the condemn or criticism conveyed by speaker A of the hate speech, which reads "... Anda aja manajemen nya lemah! Bansos aja salah sasaran. PSBB diperpanjang cuma menghabiskan anggaran. Oh ya, anda mana peduli Corona, uang komitmen formula E 200M darimana tuh?..." (...You have weak management! Even got the wrong target for the Bansos (social aid). The PSBB was extended only to spend the budget. Oh yeah, you don't care about Corona, where do you even get the commitment money for the E $200 \mathrm{M}$ formula...). Through that excerpt, there are four criticisms put forward by the hate speech speakers, namely management, Bansos (social aid), PSBB, and the E 200M formula. Hate speech speaker B also conveyed criticism about press conferences. Speaker B criticized that the party in question only liked press conferences rather than going to the field to check on their citizens.
C-A: hidup anda terlalu bar bar mbak.. lebih dari pemikiran binatang.

This criticism indicates that the argument on the hate speech in data 2 is intended to rail the actions of certain parties with harsh words. The harsh words used are in the form of hate blasphemies, such as "...gubernur bejat!!!", “...spesialis gub tukang bacot.”, "Dasar gak punya malu dan Otak" (..lecherous governor!!!", "... a governor whose specialty is talking.", "You have no shame and no brain)

Harsh words are used in the above excerpt of utterances. The act of railing with harsh words, in disrespectful language, does not really support the efforts to dignify the language (Stilz, 2015). Indonesian language will be a dignified language, if the language is used wisely, politely and respectfully, so that the public both inside and outside the country will use the language to accommodate many interests. (Ningrum, Waluyo and Winarni, 2017).

\section{Data 2 Covid-19 Hate Speech}

An invitation to be discipline in carrying out all the steps of \#PSBBJakarta

A: Ngomong disiplin? Anda aja manajemen nya lemah! Bansos aja salah sasaran. PSBB diperpanjang cuma menghabiskan anggaran. Oh ya, anda mana peduli Corona, uang komitmen formula E 200M darimana tuh? Anda gubernur bejat!!!

(Talking about discipline? You have weak management! Even got the wrong target for the Bansos (social aid). The PSBB was extended only to spend the budget. Oh yeah, you don't care about Corona, where do you even get the commitment money for the E 200M formula? You're a lecherous governor!!!)

B: Si abas bin abud ini spesialis gub tukang bacot. Gub lain keliling ngecek dan ricek warganya, Nah lu cmn kompres2 doang Dasar gak punya malu dan Otak

(This abas bin abud is a governor whose specialty is talking. Other governors are patrolling around to check the citizens, but you just always hold press conferences. You have no shame and no brain). https://twitter.com/aniesbaswedan/status/1249929633463595008

Context:

Let's be discipline in carrying out all the steps of \#PSBBJakarta to live healthy and comply with all health protection procedures. Let's save all, protect all, and the best protection is preventing transmission of COVID-19, not treating it.

\section{Conative Meaning to Create Chaos with Religious Nuances}

Arguments in the Covid-19 hate speech are also intended to reveal the conative meaning of satire. For example, in data 3 , speakers of hate speech A, B, C, D, E, and F insinuate one party to another. The hate speech which ended up being noisy with the response of the hate speech speaker J, who criticized him with harsh words. This was revealed because of the insinuation conveyed by speakers of the hate speech $\mathrm{F}$, which reads "mngkin soalnya sempat rame kalo petamburan itu markas FPI yg ktanya daerah surgawilah, kunci surga dll. Eh malah kena korona. Tapi ternyata maaf malah yg di Sekolah itu yg banyak." (maybe the problem was that it was greatly discussed that Petamburan was the FPI headquarters which was said to be the area of heaven, the key to heaven, etc. But then they are even infected with corona. But it turns out, sorry, that there are many cases at school). From the data excerpt, the researcher saw that there was insinuation purpose, and the intention of the insinuation was to create chaos with religious nuance. Hate speech in such manifestations tends to be risky because it contains nuances which are very sensitive to social responses.

Published By:

Blue Eyes Intelligence Engineering

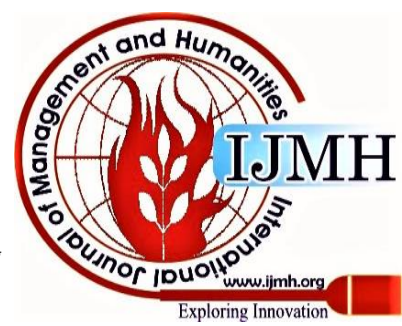


In addition to contradicting with the efforts to dignify the language, the use of the Indonesian language in this manner is also against the priority of the essential functions of language. (Sudaryanto, 2015).

The Indonesian language should be used to support and create good communication. With good communication and interaction, there will be synergy in the cooperation between national and international communities (Suwardjono, 2008).

\section{Data 3 Covid-19 Hate Speech}

Picking up 27 STTBI Students Who are Positive for Covid-19

A : Ini Deket rumah gw.. yg kena Kristen semua

(This is near my house.. all infected people are Christians)

B: Sayangnya Corona ga pandang ras, suku, agama, usia, gender, kaya-miskin. Semua sama.

(Unfortunately, Corona doesn't look at race, ethnicity, religion, age, gender, rich and poor. Everything is the same.)

C-B: lah yg mandang itu semua siapa?

(Who even said it looks at all of

them?)

D-A: STTBI itu sekolah teologia Kristen

(STTBI is a Christian theological school)

E-A: kok bisa kenapa ni mas.. (how come this happens bro...)

F-B: mngkin soalnya sempat rame kalo petamburan itu markas FPI yg ktanya daerah surgawilah, kunci surga dll. Eh malah kena korona. Tapi ternyata maaf malah yg di Sekolah itu yg banyak.

(maybe the problem was that it was greatly discussed that Petamburan was the FPI headquarters which was said to be the area of heaven, the key to heaven, etc. But then they are even infected with corona. But it turns out, sorry, that there are many cases at school)

G-A: yg ikut jamaah tabligh di malaysia dan Gowa, ratusan org positifjg muslim semua ga ada kristennya coy!

(hey! those who join tabligh congregation in Malaysia and Gowa, hundreds of positive people are also Muslims, none of them are Christians)

H-A: Setau saya yang sekolah teologi ga musti org Kristen dek.. komen2 kamu kaya gini tu SARA ... tlg lebih hati2

(As far as I know, you don't have to be a CHristian to study in a theology school ... your comments are included into sensitive issues... please be more careful)

I-H: dia coba meluruskan coz kmrn ada yg teriak2 itu dr sumber Markas FPI (-) gitu loh yg ternyata dr sekolah tsbt ();

(she tried to straighten it because there were many people screaming that it was from the FPI Headquarters (-) but it turned out to be from that school (-))

H-I: Oh baiklah... cm jaga2 aja. krn ngeri soalnya pasca kejadian di Cikarang kmren kak.

(Oh okay ... just a precaution. because I was horrified after the incident in Cikarang, Sis)

I-H: knp dgn cikarang? Blm denger apa2 :(What's up with Cikarang? I haven't heard anything :-:)

H-I: Oh, sempet ada crash antara pak haji dan org non Muslim ibadah di rumah pas $P S B B$.

(Oh, there was a crash between a hadj and a non-moslem praying at home during PSBB)

I-H: oh yg itu (-) salah aj itu yg negor klo emang itu org2 satu rumah klo bukan ya emang ga boleh.

(Oh that one (-) it's the one reprimanding who is wrong if they are in the same house, if not then yes it's not allowed.)

H-I: iya makanya kita saling ingetin aja. takutnya situasi begini banyak yg sensi.

(yes that's why we need to remind each other I'm afraid that in a situation like this many people are being sensitive)

J : Yang bilang ini ormas fpi fix anak binatang. Sperti tulisannya deni siregar yg nuduh fpi dan umat islam yg kena padahal bukan. Anjink itu kalau bicara apa aja hoax sekalipun ga pernah kena uu ite.

(The one who says that this is FPI's work is definitely animal. Like Deni Siregar's writing who accuses FPI and Moslems who get Corona, but it is not. Damn those talking about anything even though it's hoax but never being subjected to ITE law.)

https://www.instagram.com/p/B_TLpyAnZlu/

Context:

27 STTBI students who are positive for Covid-19 in Petamburan 4 Tanah Abang, Central Jakarta were picked up to be taken to the Athlete Hospital in Kemayoran, Central Jakarta.

\section{Conative Meaning of Insulting by Using Harsh Words}

The conative meaning of inculting refers to the basic notion of "degrading". The party that is belittled can happen on a higher party to a lower party or vice versa it can also occur on a lower party to a higher party, or it can occur to both parties equally in all its aspects. However, in general, acts of insult are committed by a higher party to a lower party. The hate speech argument in data 4 as a whole is intended to be insulting using harsh words.

An indication of the conative meaning of insulting by using harsh words is presented in the excerpt which reads "Dan ternyata dia yg lebih $b * g o$ hehehe...(-)(:):-(A)". (And it turns out that he is the more idiot one hehehe...(-):(-): and in the excerpt "Slogannya "INDONESIA MAJU" tapi kerjanya ngibul doing " (His slogan is "INDONESIA FORWARD" but his work is merely bullshit).

The hate speech with the meaning of insulting is aimed at the party with the highest position. The word " $b$ * $g o$ " (bego=idiot) and "ngibul" (bullshit) are harsh words that are not appropriate to be conveyed to certain parties of a higher position. In addition to the conative meaning of insulting using harsh words, there is a subordinate conative meaning of the hate speech argument.

The subordinate conative meaning of data 4 argument is insinuating. The insinuation is shown from the excerpts of hate speech that reads "Gw kirain Di Dunia ini gw yg paling

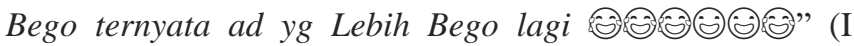
thought I am the most idiot person in this world, but it turns out that there is someone who is even more idiot

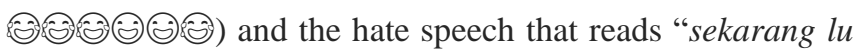
pasti bersyukur bang, ada yang lebih -:0" (now you must be grateful, bro, because there's someone who is more idiot than you (:))

The expression "lebih bego lagi" (more idiot) are words that indicate sarcasm. The conative meaning of insinuating can also be seen in the expression "diatas langit masih ada langit broo" (above the sky there is still sky broo) and "kelak km juga bs jd presiden brooo" (one day you can be also be a president brooo).

Language that is used roughly for the purpose of insulting will only result in social violence. The use of Indonesian for the creation of social violence is clearly at odds with the nature of the language itself (Rahardi, 2019). Language is an indicator of the speaker, if the language sticks out with violent, rude, impolite forms, the speaker of that language is certainly not far from that character.

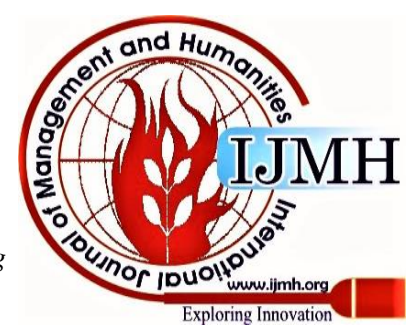


Data 4 Covid-19 Hate Speech

The Difference between Homecoming and Returning Home According to President Jokowi

A : Gw kirain Di Dunia ini gw yg paling Bego ternyata ad yg Lebih

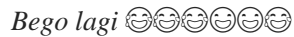

(I thought I am the most idiot person in this world, but it turns out that there is someone who is even more idiot (1):-

B : sekarang lu pasti bersyukur bang, ada yang lebih" (-); (now you must be grateful, bro, because there's someone who is more idiot than you (:))

C-A: Dulu, gua berpikir begitu jg bang wkwk

D-A: diatas langit masih ada langit broo (above the sky there is still sky broo)

E-A: kelak km juga bs jd presiden brooo (one day you can be also be a president brooo).

F-A: next presiden lu kalo fix begonya bangetmah (next president will be you if the level of idiocy is extreme)

G-A: Dan ternyata dia yg lebih $b^{*}$ go hehehe...(-):-) (and it turns out that he is the more idiot hehehe...(-)

$\mathrm{H}$ : Ternyata virus covid 19 sdh nyerang otak juga...tuh buktinys (turns out that Covid-19 virus also attacks brains...that is the evidence)

I : Mules denger'ya..

(my stomach hurts hearing this)

$\mathrm{J} \quad$ : Bwahahaha.....ikut aje Pa......ampe negara ancur...

(Hahahaha.... After you, Sir.., until this nation is ruined...)

$\mathrm{K}$ : Slogannya "INDONESIA MAJU" tapi kerjanya ngibul doang (His slogan is "INDONESIA FORWARD" but his work is merely bullshit)

L : Pemimpin sama mentri keblinger semua (The leader and the ministers are all distracted)

M: Sakit perut $w$ ketawa geli denger jawaban orang bodoh

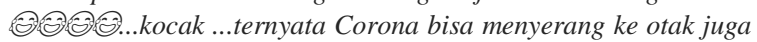
yaa...maka nya jadi begitu tuh Pak RT...RT nya siape sih ntuh@-(i)

(My stomach hurts because of laughing hearing a fool's answer (2) that's why the leader becomes like that.. whose leader is it anyway (9):-(;)

Context:

The account @jakartainformasi re-posted the conversation video between Najwa Shihab and President Jokowi about the differences between homecoming and returning home according to President Jokowi.

\section{E. Conative Meaning of Harassing}

The conative meaning of harassing implies rude rejection of something that is deemed incompatible with the will of the hate speech speakers. The conative meaning that is meant in the whole argument in data 5 hate speech can be categorized into acts of harassment. Acts of harassment of a policy can be found in most hate speech speakers. Several indicators that lead to harassment can be identified from the words "Masa Bodo!" (Whatever!) which is conveyed by speaker A; speaker B conveys it with the expression "gak ngaruh" (doesn't matter), speaker $\mathrm{C}$ expresses it with the words "makin banyak kejahatan, tolol" (there are more and more crimes, idiot) and "gara2x psbb udah ada yang mati kelaparan" (because of PSBB someone already starved to death).

In the excerpt of the utterance, it is clear that Indonesian language is used in hate speech with the intention of harassing. Something that is harassing must have negative dimensions. The language that should be used to glorify creation is used against it, to harass others (Rahardi, 2015).

If the society does not immediately develop their critical awareness with this analysis of hate speech, in the future, not only the Indonesian people who own that language who will suffer, but also the Indonesian language's dignity will fall. (I used to think like that too, bro wkwk)

https://www.instagram.com/p/B TSX5knCVN/

(Goddard, 1997). The efforts to internationalize Indonesian language, which have been very intensively carried out by the government, can be self-harassed due to the actions of the hate speech makers and perpetuators.

\section{Data 5 Covid-19 Hate Speech}

PSBB Implementation Period in Jakarta is Extended until 22 May 2020

A : Pak@aniesbaswedan terserah anda saja pak, Masa Bodo! Saya sudah 1 Minggu narik keliling nyari Order tapi Nihil engga ada yang masuk sama sekali, daripada saya harus di rumah terus banyak pikiran dan tidak ada pemasukan lebih baik kami mati di jalan pak "Rasa Lapar tidak kenal hari libur pak..."

(Mr. @aniesbaswedan It's up to you Sir, Whatever! I've been looking around for an order for 1 week but nothing comes in at all, rather than having to be at home, I have a lot of thoughts and no income, it's better if we die on the road Sir "Hunger doesn't know any holidays, Sir ...) - 20

B : betulll itu bang..PSBB juga gak ngaruh.coba liat di lapangan.masih banyak yg berboncengan kendaraan roda 2.di angkutan umum juga sama..udah lah ora usah pake PSBB segala..bikin ribet doangan.matiin rezeki banyak orang. (that is very true bro ... PSBB also doesn't matter. I still see many people who ride motorcycles together. The same case on public transportation ... just forget PSBB ... it only makes it more complicated pray and kill many people income)

A-B: lihat saja bang habis lebaran kalau tidak bisa tangani , banyak orang yang bakal masa Bodo sama ini wabah...

(Just wait and see until after the Eid bro, if they can't handle it, many people will be ignorant to this plague)

C : woy gubernur kalo di perpanjang alhasil makin banyak kejahatan, tolol

(hello governor, if it is extended the result is more crimes, idiot)

D-C: klo ga di perpanjang makin byk korban tolol, medis udh byk yg tumbang. Kalo semua medis tumbang, siapa yg ngobatin???? (if it's not extended, there will be more victims, idiot, many medical staff have already died. If all the medical staff die, who will treat them????)

C-D: kalo di perpanjang seharusnya lu juga mikir tolol. gara2x psbb udah ada yang mati kelaparan gara2x usahanya di gak gerak. (if it's extended, they should think too, idiot. PSBB has caused someone to die out of hunger because his business stopped running)

E-C: kalau mau komen mikir + ngaca mas ya, lo mau tambah banyak korban dan team medis pada meninggal, pikiri dl lah

(if you want to comment, please think about it first and look into the mirror, bro, do you want more victims and the medical staff to die, just think about it first.)

D-C: semua kena dampak, Psbb bgni, pusat juga harus bergerak. Dan ga mungkin kebijakan ga di dpt dr pusat. Indeks komen lu, ke gubernur.

(all are affected, during Psbb, the central government must also move. And there's no way that the policy isn't instructed from the central government. Index your comment to the governor)

C-E: itu berbalik kepada diri anda .anda kan taunya cuma dari medsos belum tau validasi depan mata kepala sendiri

(it's all back to you. You know only from social media, you don't know the validation before your own eyes)

C-D: lah fakta bos yg di banten mati karena kelaparan gak dapat anggaran dana cuma gara2x psbb

(It is a fact, boss, in Banten there's someone who died because of starvation and he did not get any money just because of PSBB)

E-C: cape gua sma cebong (cebong makes me exhausted)

F-C: kan di banten mas, kok nyasar nya ke Jakarta. Kalo gitu complain nya ke pusat dong

(it's in Banten, right bro, how come it strayed to Jakarta. If that's the case, please complain to the central government)

G-C: lah yang mati di Banten kenapa lu misuh-misuh nya ke Gubernur Jakarta ???

(the person who died is in Banten, then why did you curse the governor of Jakarta???)

Published By:

Blue Eyes Intelligence Engineering

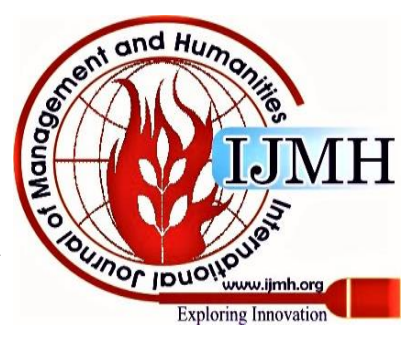


H : yang suka ngomong, selamat dari corona tapi mati kelaparan, , , mau nanya sekaya apa si lu di kampung nyaधि, mau maksa balik kampung krn minim bantuan, emang ente bisa jamin apa kalo bawa virus ke kampung halaman, eh elu mati karena corona mah bodoamat, , masalah nya mayat lu yg kena corona itu bikin masalah baru buat org² di kampung lu coooook... Udah numpang nyari duit di kota orang giliran ada kaya gini kau bertingkah pula, ya tolong gitu pikirrrr pake otak famine,,, i want to ask how rich are you in your village 10 forcing yourself to return to the village because there's no aid, how can you guarantee that you dont bring the corona virus to your village, if you die because of corona, whatever,,, the problem is your dead body that is infected by corona creates new problems for the people in your village ... You have been earning money in others' city and now in this kind of situation you act like that, please just think using your brain)

https://www.instagram.com/p/B_SIGT9ntsP/

\section{Context:}

The Governor of DKI Jakarta, Anies Baswedan officially announced the extension of the Large-Scale Social Restrictions (PSBB) implementation in Jakarta until 22 May 2020. Anies conveyed the decision at a press conference at City Hall, broadcasted live via the DKI Jakarta Provincial Government's Youtube account on Wednesday, April 22.

\section{CONCLUSION}

As a conclusion, it can be reiterated that this study has succeeded to find eight subordinate conative meanings of Covid-19 hate speech. The eight conative meanings of Covid-19 hate speech are: (1) insulting, (2) criticizing, (3) railing, (4) provoking, (5) harassing, (6) blaspheming, (7) insinuating, and (8) defaming a good name. Even so, the researcher realizes that this study is still limited to the data on Covid-19 hate speech obtained in March-April 2020.

With more data and a longer time span, more conative meanings of Covid-19 hate speech will be found because there are relatively more data. In a larger study, the researcher will conduct a more comprehensive study so that the description of conative meanings of the Covid-19 hate speech will be better.

\section{ACKNOWLEDGEMENT}

Researcher would like to thank Sanata Dharma University for supporting this research.

\section{REFERENCES}

1. Ameka, F. (1992). 'The meaning of phatic and conative interjections', Journal of Pragmatics. doi:10.1001/jama.291.23.2840.

2. Education, L. (2019). 'Argumentative essay in the perspective of Toulmin's model: needs of evoluting Indonesian society from spoken culture to written culture' doi: 10.4108/eai.21-12-2018.2282774.

3. van Eemeren, F. H. et al. (2013). 'Toulmin's model of argumentation', in Handbook of Argumentation Theory. doi: 10.1007/978-94-007-6883-3 4-1.

4. Ephratt, M. (2008). 'The functions of silence', Journal of Pragmatics. doi: 10.1016/j.pragma.2008.03.009.

5. Goddard, C. (1997). "Cultural values and "cultural scripts" of Malay (Bahasa Melayu)', Journal of Pragmatics. doi: 10.1016/S0378-2166(96)00032-X.

6. Kneuper, C. W. (1978). 'Teaching argument: an introduction to the Toulmin model', College Composition and Communication. doi: 10.2307/356935.

7. Krippendorff, K. (2010). 'Content Analysis: An Introduction to Its Methodology (2nd ed.).', Organizational Research Methods.
(Those who like to say, safe from corona but die because of

8. Krippendorff, K. (1993). Analisis Isi: Pengantar Teori dan Metodologi. Terjemahan Farid Wajidi. Jakarta: RajaGrafindo Persada.

9. Mahsun, M. (2005). Metode Penelitian Bahasa, Jakarta: PT Raja Grafindo Persada. doi: 10.1200/JCO.2008.17.1991.

10. Ningrum, D. J., Suryadi, dan Wardhana, D. E. C. (2018). Kajian ujaran kebencian di media sosial. Jurnal Ilmiah Korpus, Volume II, Nomor III, Desember 2018.

11. Ningrum, R. K., Waluyo, H. J. and Winarni, R. (2017). 'BIPA (Bahasa Indonesia Penutur Asing) sebagai upaya internasionalisasi universitas di Indonesia', Procedings of Education and Language International Conference.

12. Rahardi, K. (2019). 'Pragmatic perspective on phatic functions and language dignity in a culture-based society', Asia Proceedings of Social Sciences. doi: 10.31580/apss.v4i1.554.

13. Rahardi, R. K. (2009). Bahasa Indonesia untuk Perguruan Tinggi. 1st edn. Jakarta: Erlangga.

14. Rahardi, R. K. (2015). 'Menemukan hakikat konteks pragmatik', Prosiding Seminar PRASASTI. doi: 10.20961/PRAS.V0I0.63.G47.

15. Rahardi, R. K. (2018). 'Konstelasi kefatisan dalam teks-teks natural religius dengan latar belakang kultur spesifik', in Prosiding Kongres Internasional Masyarakat Linguistik Indonesia 2018.

16. Schilling, J. (2006a). 'On the Pragmatics of Qualitative Assessment', European Journal of Psychological Assessment. doi: 10.1027/1015-5759.22.1.28.

17. Schilling, J. (2006b). 'On the pragmatics of qualitative assessment', European Journal of Psychological Assessment. doi: 10.1027/1015-5759.22.1.28.

18. Setyaningsih, Y. and Rahardi, R. K. (2018). 'Douglas Walton's argumentation models in the vehicle of the Indonesian language internationalization', KnE Social Sciences. doi: 10.18502/kss.v3i9.2616.

19. Setyaningsih, Y. and Rahardi, R. K. (2019). 'Quality of arguments used in the first-round presidential debate: critical pragmatics and Stephen Toulmin's perspective', International Journal of Engineering and Advanced Technology, 8(5C), pp. 716-725. doi: 10.35940/ijeat.e1102.0585c19.

20. Siswantoa \& Ermanto. (2019). Analisis kesantunan berbahasa tokoh politik nasional Prabowo Subianto pada pidato kebangsaan "Indonesia Menang”. SALINGKA: Majalah Ilmiah Bahasa dan Sastra, Volume 16 Nomor 2 Edisi desember 2019, p. 81-92.

21. Stilz, A. (2015). 'Language, dignity, and territory', Critical Review of International Social and Political Philosophy. doi: 10.1080/13698230.2015.1023632.

22. Sudaryanto (2015). Metode dan Aneka Teknik Analisis Bahasa: Pengantar Penelitian Wahana Kebudayaan secara Linguistis. 1st edn. Yogyakarta: Sanata Dharma University Press.

23. Sudaryanto (2016). Metode dan Aneka Teknik Analisis Bahasa. 1st edn. Yogyakarta: Sanata Dharma University Press.

24. Suwardjono (2008). 'Peran dan martabat bahasa Indonesia dalam pengembangan ilmu', Kongres IX Bahasa Indonesia. doi: 10.231/JIM.0b013e3182508317.

25. Setyaningsih, Y. (2013). 'Metakognisi sebagai keterampilan melatih siswa berpikir kritis dalam pembelajaran bahasa', in Yuliana Setyaningsih dan R. Kunjana Rahardi (ed.) Prosiding Seminar Nasional PBSI, FKIP, Universitas Sanata Dharma. Yogyakarta: Universitas Sanata Dharma, p. 166. http://digilib.uinsby.ac.id/15465/4/Bab\%202.pdf. https://www.hukumonline.com/berita/baca/lt5cf0a71edb75c/ 28. meluruskan-istilah-kritik--fitnah-dan-ujaran-kebencian-oleh--r eda- manthovani/ https://kbbi.kemdikbud.go.id/

29. https://litigasi.co.id/hukum-pidana/62/jeratan-hukum-ujarankebencian-hate-speech.

Published By:

Blue Eyes Intelligence Engineering

\& Sciences Publication

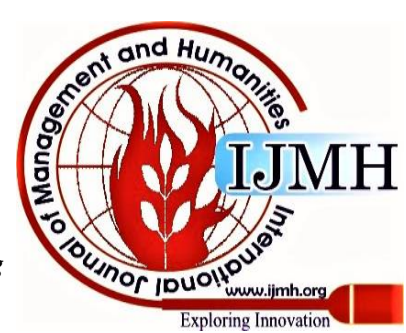


30. https://litigasi.co.id/hukum-pidana/62/jeratan-hukum-ujaran-k ebencian-hate-speech.

\section{AUTHOR's PROFILE}

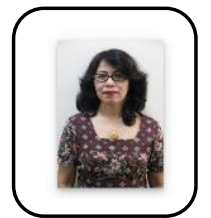

Dr.Yuliana Setyaningsih, M.Pd., was born in Surakarta on October 1, 1963. She serves as the Lecturer of Indonesia Language and Literature Education Study Program, Faculty of Teachers Training and Education, Sanata Dharma University, Yogyakarta. She served as the Head Department of the Indonesian and Literature Study Program for two periods starting from 2009 until 2017.

She graduated from the Doctorate Program of Indonesian Education University in Indonesian Education Teaching Study Program in January 2007. The textbooks during her doctorate tenure are: Fonologi dalam Bahasa Indonesia (Universitas Sanata Dharma Press, Yogyakarta, 2014), Pragmatik: Fenomena Ketidaksantunan Berbahasa (Erlangga Publisher Jakarta, 2016) as the co-writer, Menulis Artikel Jurnal: Panduan Mencipta Karya Ilmiah Bermutu dengan Pengembangan Argumentasi Berperspektif Stephen Toulmin (Amara Books Publisher Yogyakarta, 2018) Model Peningkatan Kualitas Argumen Paragraf-paragraf Argumentatif Bagian Pembahasan Artikel Jurnal Terakreditasi, Amara Books Publisher Yogyakarta, 2017), Kefatisan Berbahasa: Studi fenomena kebahasaan dalam perspektif sosiokultural dan situasional, Amara Books Publisher Yogyakarta, 2017) as the co-writer. She did her thoughts in Indonesian Language Teaching, Evaluation, Curriculum Development, and Critical Writing based on Toulmin"s Model and they have been exposed in various national and international forums documented in various proceedings and journal articles. Joining with her colleague, she also did some researches on Pragmatics, Sociopragmatics, and Ecolinguistics.

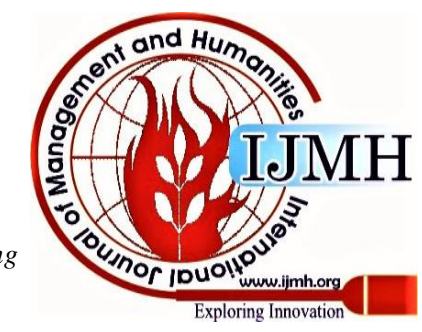

